\title{
Finite Element Analysis of Tie Beams under the Effect of Differential Settlement of Isolated Footings
}

\author{
A. M. Basha ${ }^{a^{*}}$, M. I. Salama ${ }^{a}$ \\ ${ }^{a}$ Lecturer, Department of Civil Engineering, Faculty of Engineering - Kafrelshiekh University, Egypt.
}

Received 29 May 2017; Accepted 14 September 2017

\begin{abstract}
The main objective of this paper is numerical analysis of the tie beams of isolated footings under the effect of differential settlement. 3-D simulation of the tie beams connected to isolated footings system by the finite element method was conducted. The numerical results were compared with the results of mathematical simulation of the tie beams given by previous research to determine the coefficient of semi rigid connection. The numerical result illustrate that the bending moments carried by the tie beam increase as the isolated footing width increased. Charts presented in the current paper show the effect of each parameter in the straining actions of tie beams that can be simply used by design engineers.
\end{abstract}

Keywords: Tie Beam; Differential Settlement; Isolated Footings; Soil Reaction; Finite Element.

\section{Introduction}

Tie beams are usually connecting isolated and strip footings at the foundation level to improve their settlement resistance and increase the foundation system stiffness. It used to carry the ground floor partitions, decreasing the differential settlement between footings and increase the foundation system stiffness. However tie beams are widely used around the world, there is no closed form for analysis or design of tie beams. But there are a common practice criteria and some codes and standards suggestion [1-5].

Indian Standards IS 1893 (2002) state that isolated footings or pile caps shall be interconnected with ties in some specific seismic zones for soil types other than rocks. These ties shall be able to carry an axial force equal to a seismic factor Ah/4 times the larger of the column or pile cap load [6]. Massachusetts state building code and the Egyptian code require that all ties shall be capable of resisting, in tension or compression, a force equal to $10 \%$ of the larger total column load $[7,8]$.

International Building Code 2009 state that the force to be resisted by the ties equals to the lesser of the product of the larger footing design gravity load times a seismic coefficient, SDS, divided by 10 and 25 percent of the smaller footing design gravity load [9].

Al-Omari et al. (2008) investigated numerically by using ANSYS software, the effect of tie beams on settlement, moments and shear of footings. The results indicated that the tie beams reduce the total and differential settlements of footings but this restriction is often on the expense of increasing the shear and moment particularly in the central footing. However, the settlement reduction may be considered invaluable in view of avoiding the excessive stresses in beams and slabs of the superstructure [10].

\footnotetext{
* Corresponding author: ealibasha@yahoo.com

DOI: http://dx.doi.org/10.21859/cej-03092
}

$>$ This is an open access article under the CC-BY license (https://creativecommons.org/licenses/by/4.0/).

(C) Authors retain all copyrights. 
Almasri et al. (2012), using finite element analysis of three dimensional structural models, presented that how the structural resistance to settlement can be improved by tie beams between footings. Also, seismic analysis is performed to investigate the tie beams behavior under dynamic loading in improving structural performance of foundation system. Results indicate that tie beams can reduce differential settlement greatly under both static and dynamic conditions [11].

M. A. El Sideek (2014) used finite element method to investigate the effect of tie beams in improving foundation resistance to settlement under static loading. Major of international codes still lacks adequate provisions on design of the tie beams and there is a shortage in research in this field. So; these need to be developed [12].

The major aim of the present paper is the concentration in the tie beams design as a structural element under the differential settlement effect directly taking all the parameters into consideration.

\section{Structural Model}

The tie beam can be represented as prismatic element connecting points A and B as shown in Figure 1. These connections at $\mathrm{A}$ and $\mathrm{b}$ are semi rigid connections that van be represented by rotational spring, on which the applied moment is equal to the product of its stiffness and the angle of rotation as stated by Wang 2014 [13].

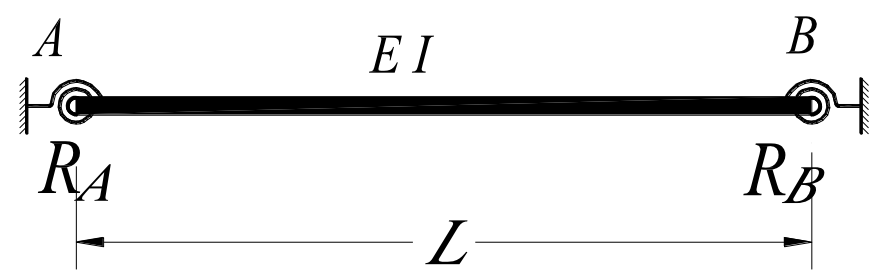

Figure 1. Structural model

$$
M_{A}=R_{A} \frac{E I}{L} \varphi_{A} M_{B}=R_{B} \frac{E I}{L} \varphi_{B}
$$

Where, $R_{A}$ and $R_{B}$ are non-dimensional quantities which are measure of degree of rigidity.

The relation between acting end moments $M_{A}$ and $M_{B}$ on the semi rigid connections and the fixed end moments $M_{A}^{F}$ and $M_{B}^{F}$ can be obtained as follows:

$$
\left(\begin{array}{l}
M_{A} \\
M_{B}
\end{array}\right)=\left(\begin{array}{ll}
s_{i i} & s_{i j} \\
s_{j i} & s_{j j}
\end{array}\right)\left(\begin{array}{c}
+\frac{1}{3} M_{A}^{F}-\frac{1}{6} M_{B}^{F} \\
-\frac{1}{6} M_{A}^{F}+\frac{1}{3} M_{B}^{F}
\end{array}\right)
$$

Where

$$
\begin{gathered}
s_{i i}=\frac{4 R_{A} R_{B}+12 R_{B}}{R_{A} R_{B}+4\left(R_{A}+R_{B}\right)+12}, s_{j j}=\frac{4 R_{A} R_{B}+12 R_{A}}{R_{A} R_{B}+4\left(R_{A}+R_{B}\right)+12} \quad \text { and } s_{i j}=s_{j i} \\
=\frac{2 R_{A} R_{B}}{R_{A} R_{B}+4\left(R_{A}+R_{B}\right)+12} \\
M_{A}^{F}=M_{B}^{F}=\frac{6 E I}{L^{2}} \Delta
\end{gathered}
$$

Thus,

$$
M_{A}=\frac{R_{A} R_{B}+2 R_{B}}{R_{A} R_{B}+4\left(R_{A}+R_{B}\right)+12}\left(\frac{6 E I}{L^{2}} \Delta\right)
$$

And

$$
M_{B}=\frac{R_{A} R_{B}+2 R_{A}}{R_{A} R_{B}+4\left(R_{A}+R_{B}\right)+12}\left(\frac{6 E I}{L^{2}} \Delta\right)
$$

Where; $\Delta$ is the differential settlement between footings. 
As stated by Wang; the end moments of the semi rigid connections equal to a ratio of the fixed end moments [13]. This ratio depends on many factors such as stiffness of the tie beam; stiffness of the isolated footing and soil stiffness. This expression can be written as follow;

$$
\begin{aligned}
& M_{A}=\alpha_{A} \frac{6 E I}{L^{2}} \Delta=\alpha_{A} M_{A}^{F} ; \\
& M_{B}=\alpha_{B} \frac{6 E I}{L^{2}} \Delta=\alpha_{B} M_{B}^{F}
\end{aligned}
$$

Where, $\alpha_{A}$ and $\alpha_{B}$ are coefficient of semi rigid connections which equal to ratio between the end moments of the semi rigid connections and the fixed end moments.

\section{Numerical Model}

Three dimensional models of two square footings with a tie beam are modeled by SAP program. Solid elements were used to model the footing and the tie beam as shown in Figure 2. The model is meshed using an 8-node linear element with a mesh size $0.20 \mathrm{~m}$ in horizontal direction and $0.30 \mathrm{~m}$ in vertical direction to get accurate results. All materials assumed to be homogeneous. Table 1. summarizes the material properties for isolated footing and soil.

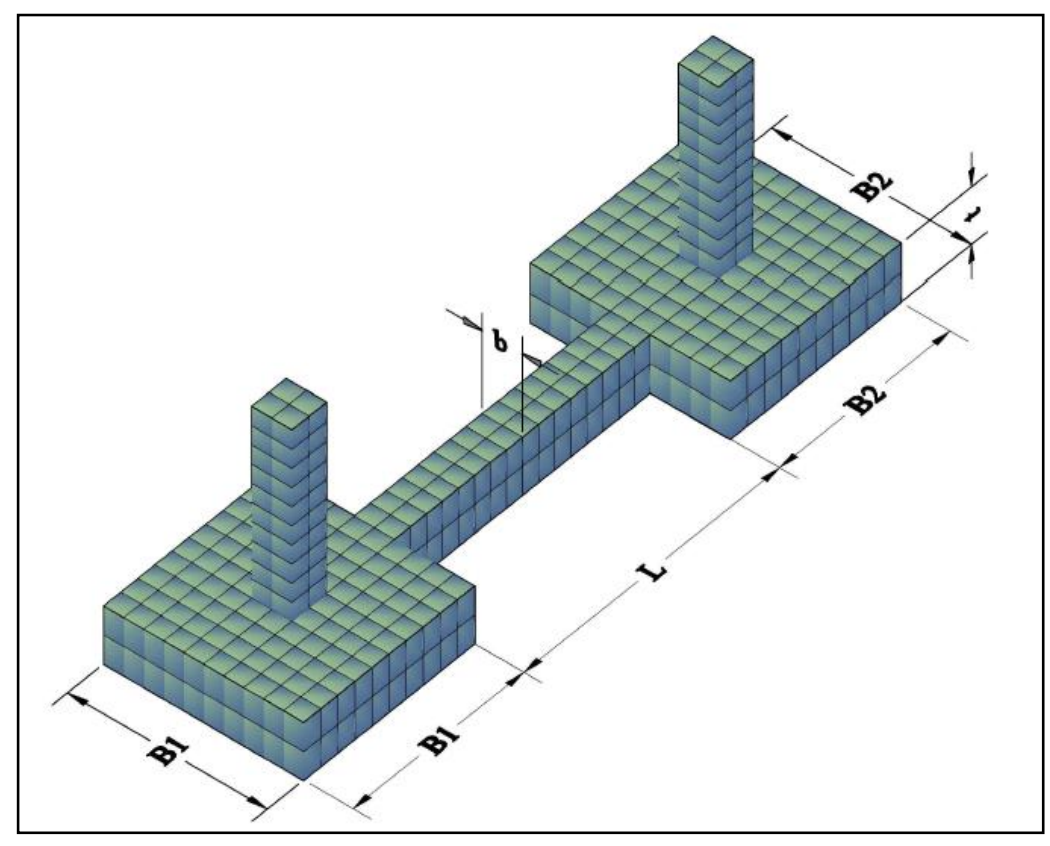

Figure 2. Structural finite element model with tie beam in three dimensional

The modulus subgrade reaction is developed on the assumption that the soil reaction of the isolated footings is proportional to the deflection of the beam at every point. The vertical settlement is represented by means of identical, independent, closely spaced, discrete and linearly elastic springs. This spring is known as the modulus of subgrade reaction as stated by Winkler, in 1867.

The numerical model based on the following assumption:

- There is no contact between the tie beam and the supporting soil;

- All material are homogeneous, isotropic and obeys Hooke's Law.

All material are homogeneous, isotropic and obeys Hooke's Law Cross-section of the tie beam is 0.40 in width and $0.60 \mathrm{~m}$ in thickness. The tie beam length was varied in three values $2.00 \mathrm{~m}$ and $3.00 \mathrm{~m} ; 4.00 \mathrm{~m}$. Footing width equal to the tie beam thickness. All footing are square where their width varied between $1.00 \mathrm{~m}$ to $3.00 \mathrm{~m}$ with increase $0.50 \mathrm{~m}$. Dimensions of all elements are presented in Table 2. 
Table 1. Material properties

\begin{tabular}{ccc}
\hline Property & Concrete & Soil \\
\hline Poisson ratio & 0.20 & 0.30 \\
Unit weight $\left(\mathrm{kN} / \mathrm{m}^{3}\right)$ & 25 & 17.50 \\
Modulus of elasticity $\left(\mathrm{KN} / \mathrm{m}^{2}\right)$ & 22000000 & 13000 \\
Bearing capacity $\mathrm{q}_{\mathrm{a}}\left(\mathrm{KN} / \mathrm{m}^{2}\right)$ & ---- & 100,200 \\
Modulus of subgrade reaction $\mathrm{K}=10 \mathrm{q}_{\mathrm{a}}\left(\mathrm{KN} / \mathrm{m}^{3}\right)$ & --- & 1000,2000 \\
\hline
\end{tabular}

Table 2. Model geometry and dimensions

\begin{tabular}{cc}
\hline Property & value \\
\hline Tie beam width $(\mathrm{m})$ & 0.40 \\
Tie beam thickness; $\mathrm{b}(\mathrm{m})$ & 0.60 \\
Tie beam length ; $\mathrm{L}(\mathrm{m})$ & $2.00 ; 3.00 ; 4.00$ \\
Isolated footing thickness $(\mathrm{m})$ & 0.60 \\
Isolated footing width; B1 and B2 $(\mathrm{m})$ & $1.00 ; 1.50 ; 2.00 ; 2.50 ; 3.00$ \\
Column dimension (m) & $0.40 \times 0.40$ \\
\hline
\end{tabular}

Figure 3. shows sample of the obtained normal stress distribution contours considering different values of the parameters that affect in the design of these tie beams (tie beam stiffness, footings dimensions, soil bearing capacity and the differential settlement value). The result indicates that the position of the maximum end moment for the tie at contact between the tie beam and the footing. Therefore; the clear length of the tie beam is considered as a critical parameter.

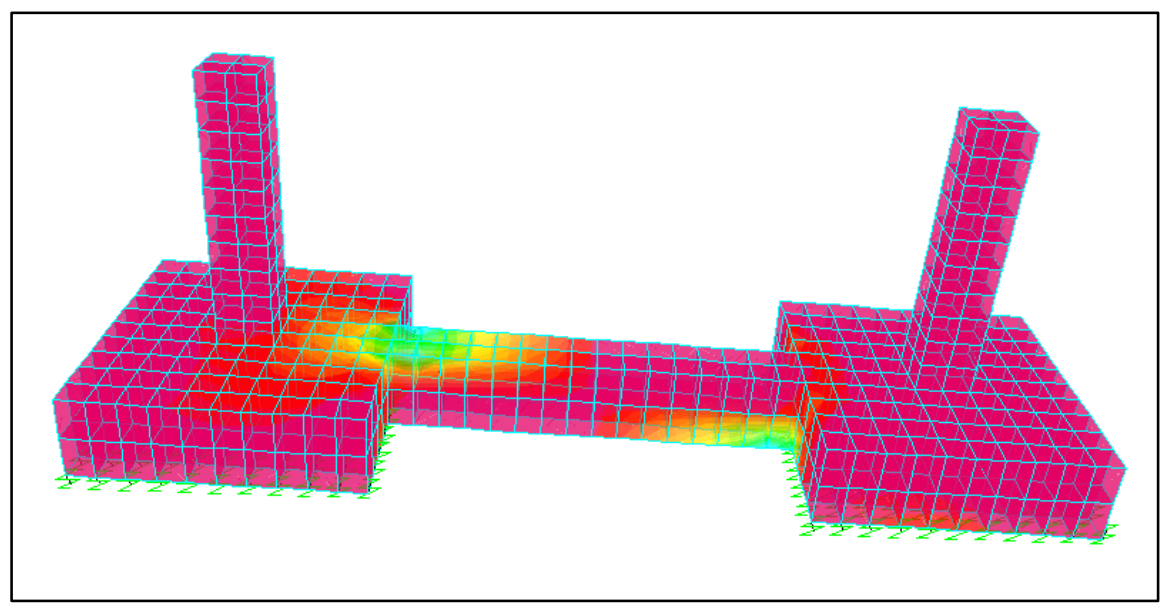

Figure 3. Sample of normal stress distribution contours

\section{Numerical Results}

\subsection{Effect of the Tie Beam Length}

Figure 4 and 5. show the effect of the tie beam length in case the tie beam connected to two equal square footing at different bearing capacity. The vertical axis represent the maximum end moment in case of semi rigid connection. As can be drawn from result; the maximum moment proportional with the tie length. The maximum moment increase as footing width increase in case of the two footing is identical in the dimension. From Figure 4; the maximum moment approximately equal 4.30 m.t when width the isolated footing equal to $3.0 \mathrm{~m}$. From Figure 5 ; the maximum moment approximately equal $8.00 \mathrm{~m} . \mathrm{t}$ when width the isolated footing equal to $3.0 \mathrm{~m}$. Based on this result; the modulus of subgrade reaction. 


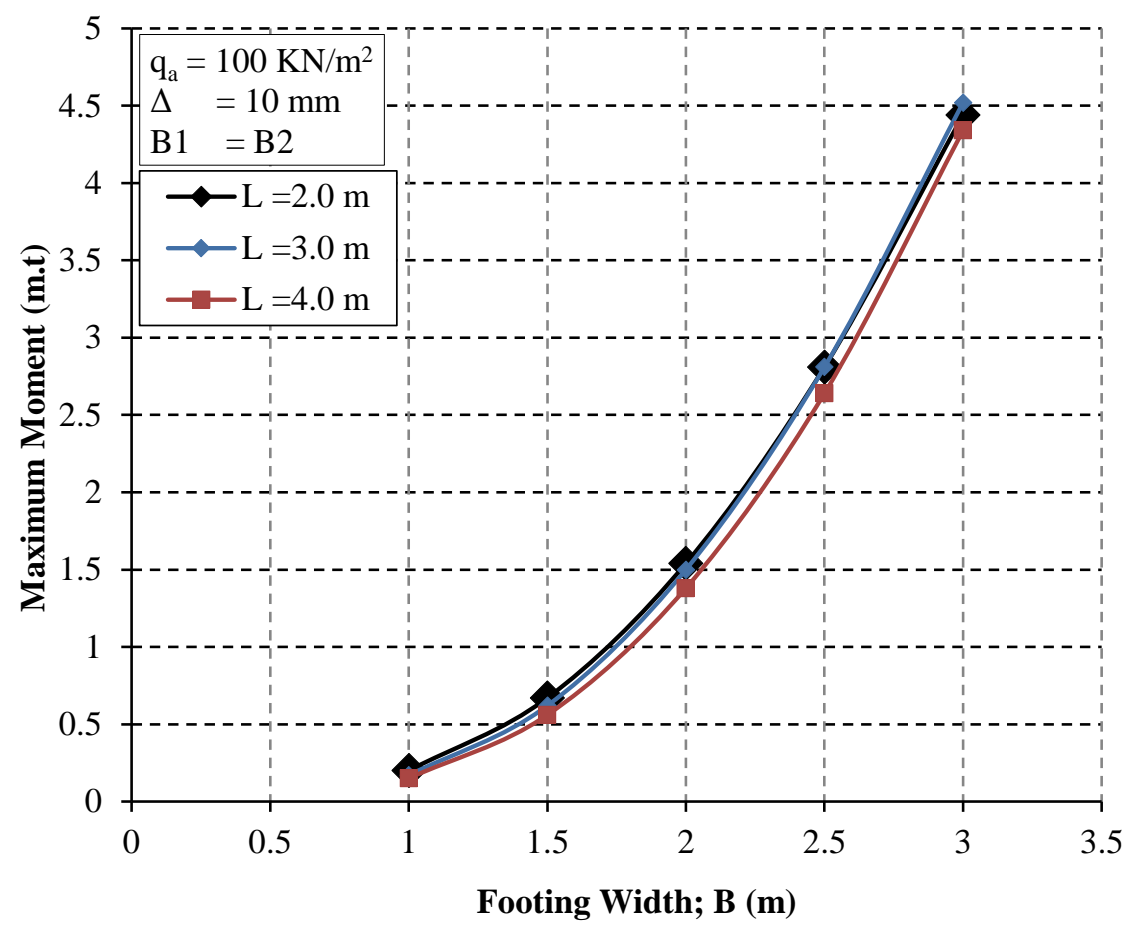

Figure 4. Relation between footing width and end moment of the tie beam at different values the tie beam length at differential settlement $=10 \mathrm{~mm}$ and soil bearing capacity $=10 \mathrm{t} / \mathrm{m}^{2}$

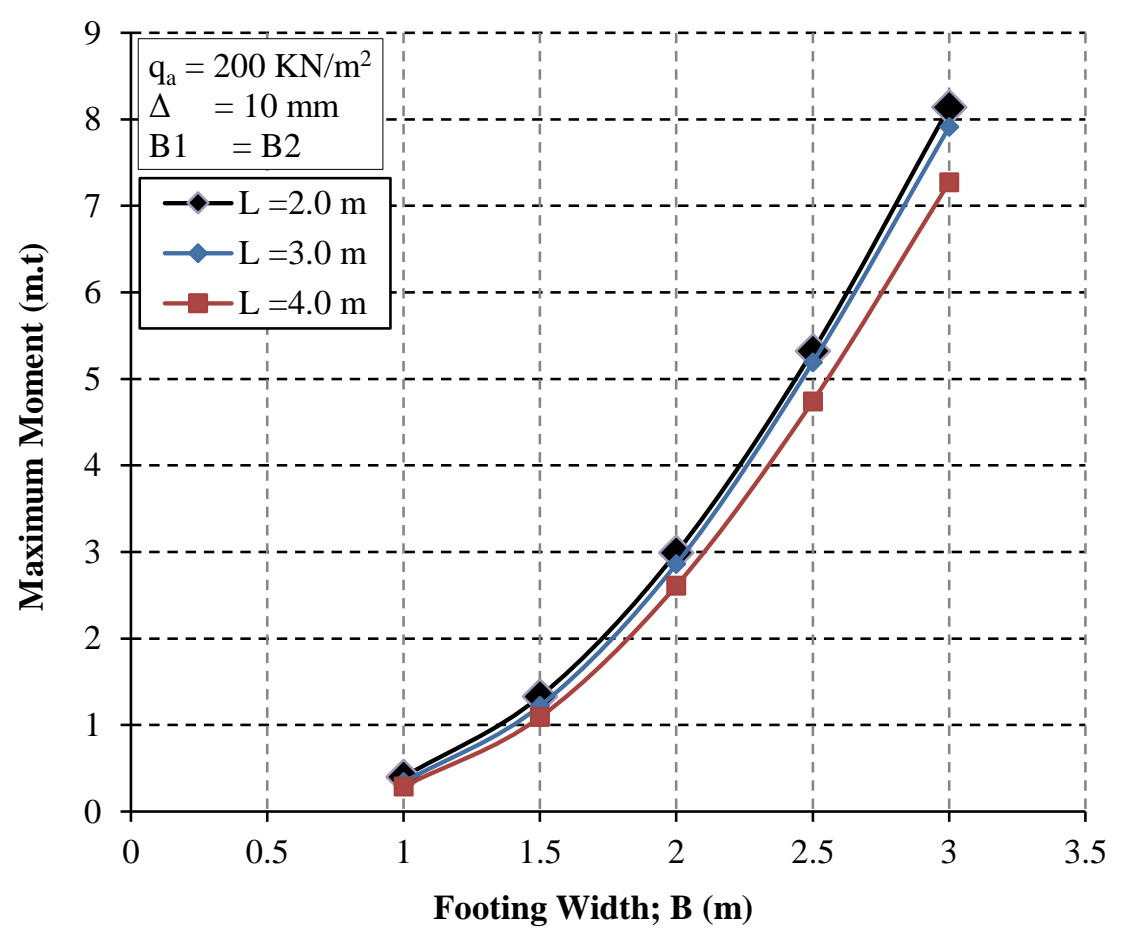

Figure 5. Relation between footing width and end moment of the beam at different values the tie beam length at differential settlement $=10 \mathrm{~mm}$ and soil bearing capacity $=20 \mathrm{t} / \mathrm{m}^{2}$

\subsection{Effect of the Footing Width}

The relationship between maximum end moment of tie beam and the footing width considering differential practical values of other parameters may be affect in the tie beam moment (tie beam stiffness, soil bearing capacity and the differential settlement value) are shown in Figures 6 to 13. 


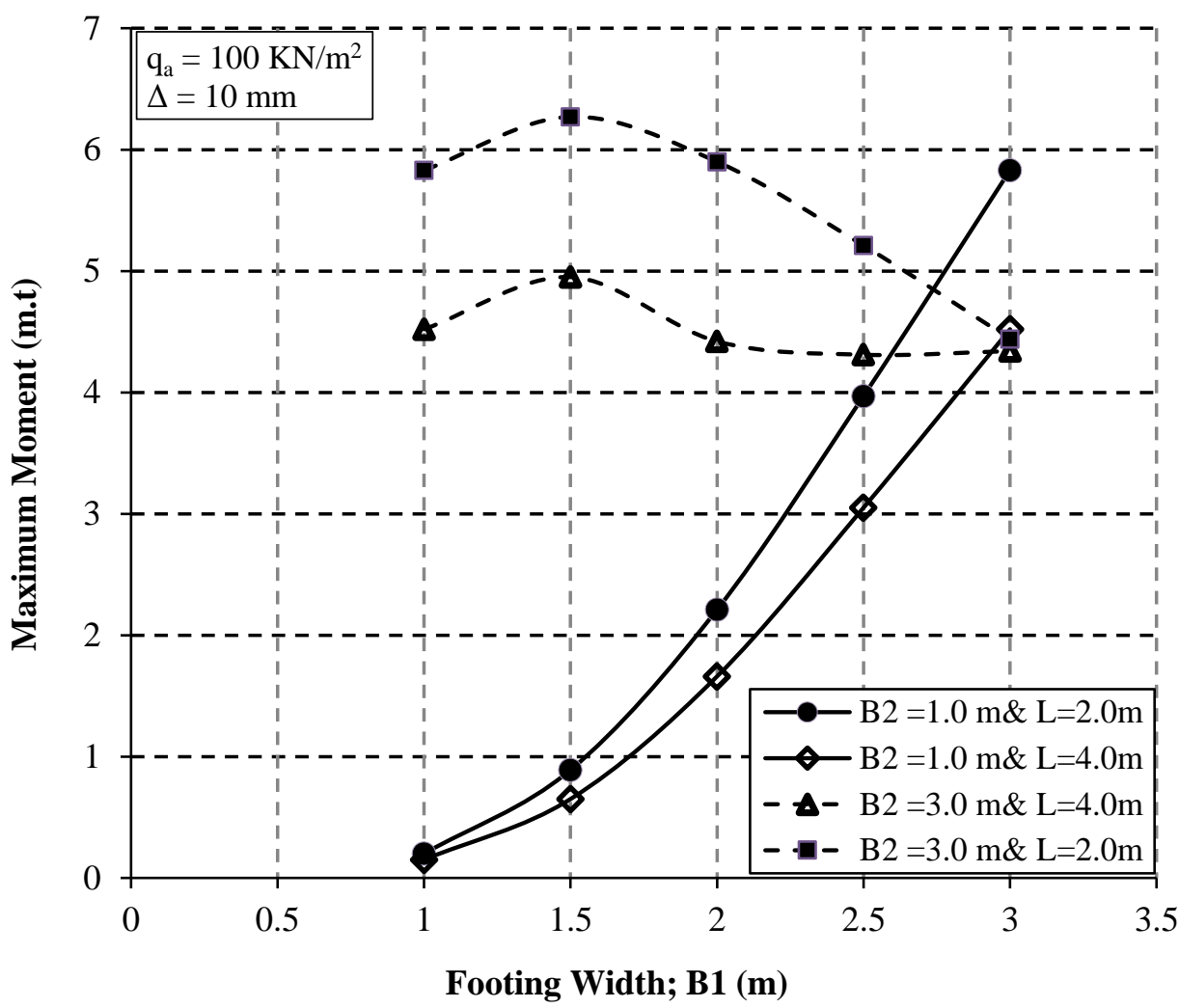

Figure 6. Relation between footing width and end moment of the beam at different values the tie beam length at differential settlement $=10 \mathrm{~mm}$ and soil bearing capacity $10 \mathrm{t} / \mathrm{m}^{2}$

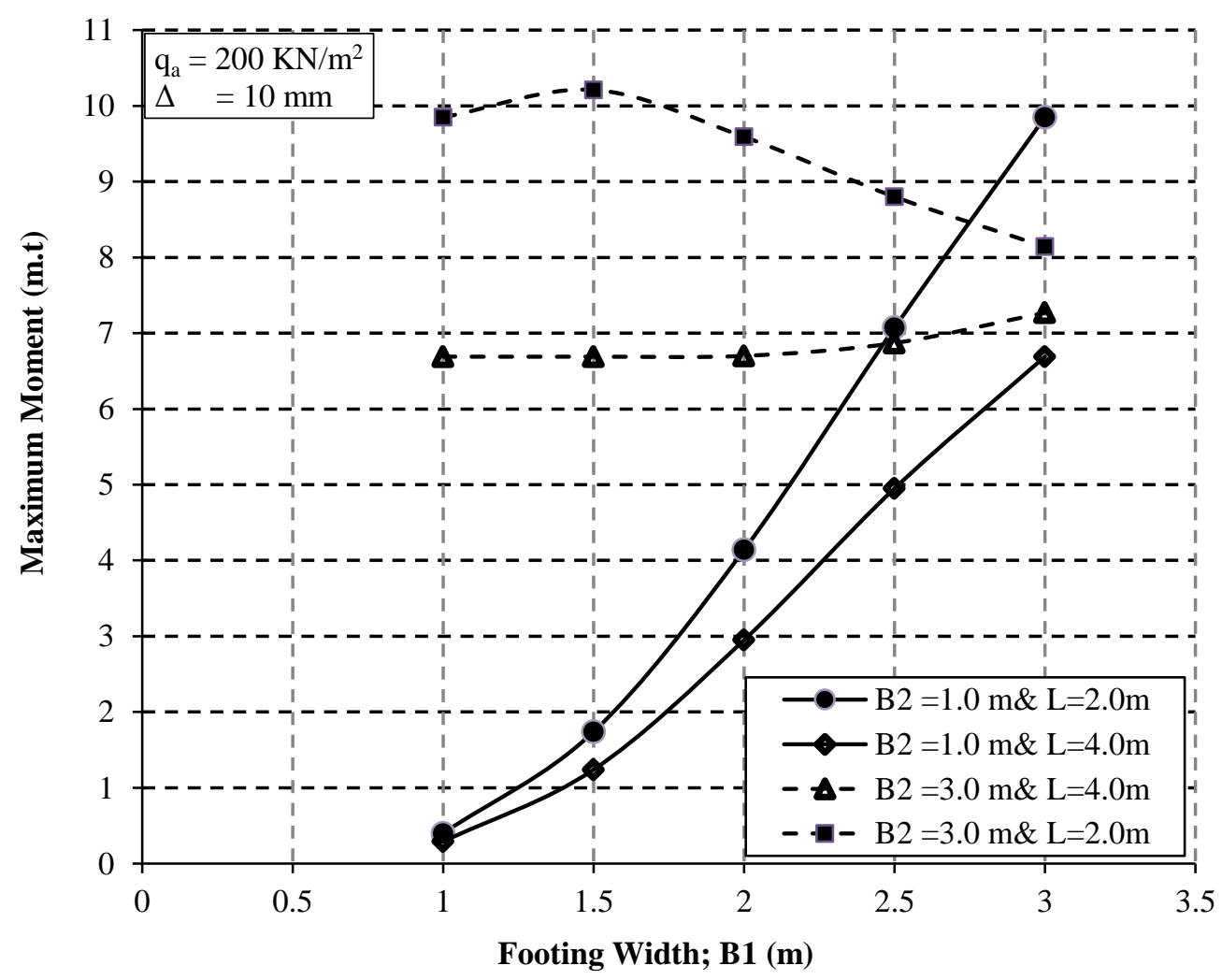

Figure 7. Relation between footing width and end moment of the beam at different values the tie beam length at differential settlement $=10 \mathrm{~mm}$ and soil bearing capacity $20 \mathrm{t} / \mathrm{m}^{2}$ 


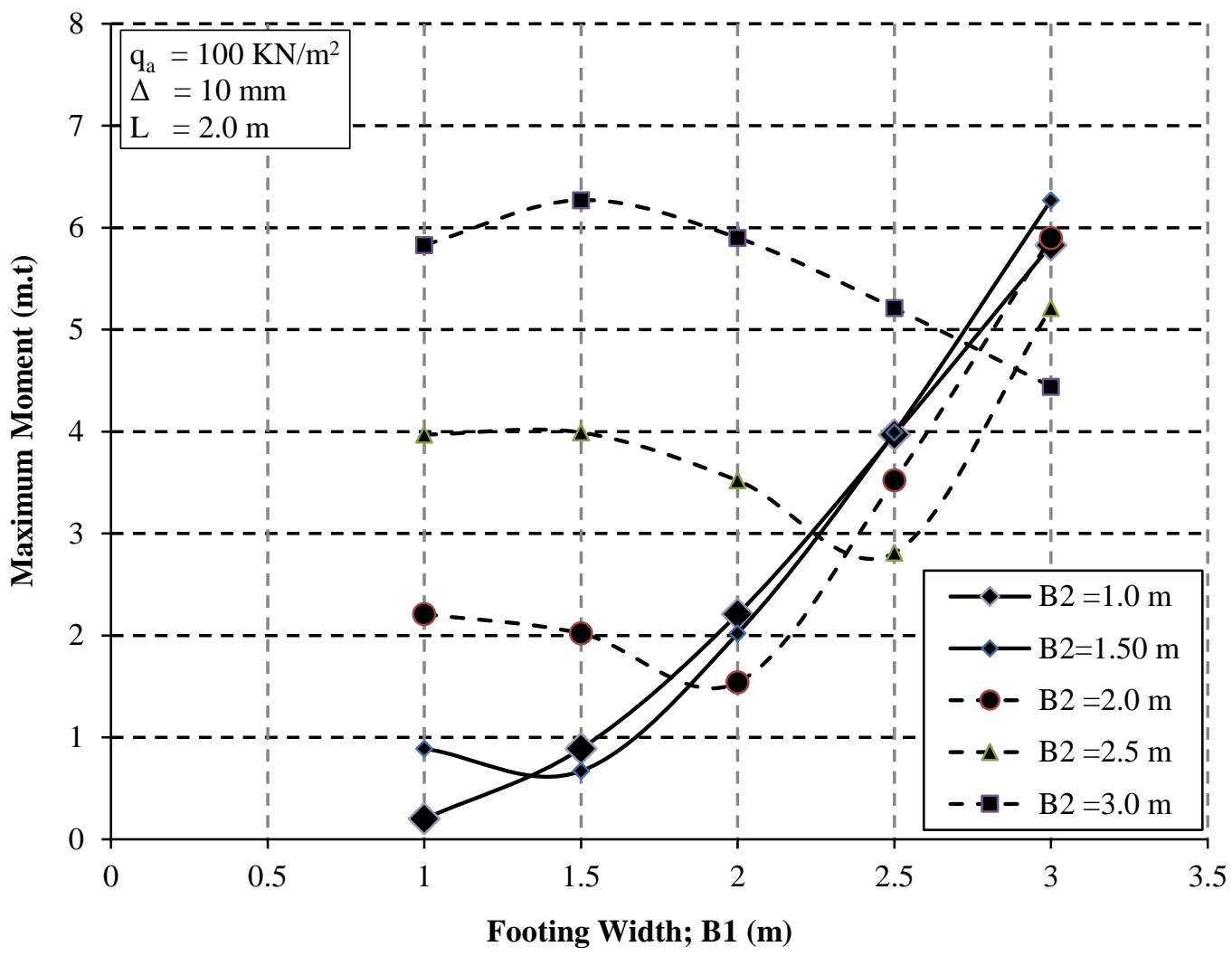

Figure 8. Relation between footing width and end moment of the beam at differential settlement $=10 \mathrm{~mm}$, soil bearing capacity $10 \mathrm{t} / \mathrm{m}^{2}$ and the tie beam length $=2.0 \mathrm{~m}$

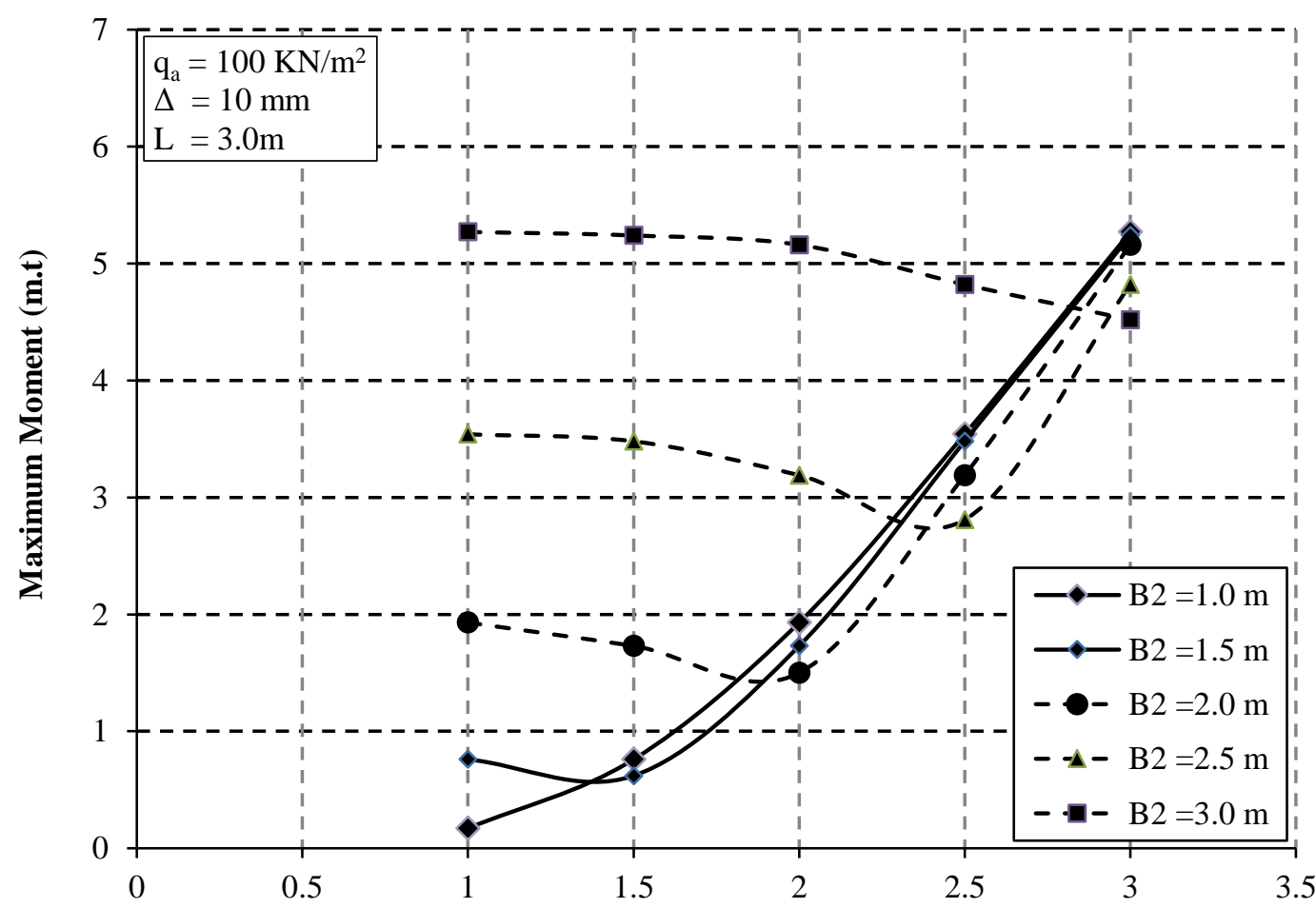

Footing Width; B1 (m)

Figure 9. Relation between footing width and end moment of the beam at differential settlement $=10 \mathrm{~mm}$, soil bearing capacity $10 \mathrm{t} / \mathrm{m}^{2}$ and the tie beam length $=3.0 \mathrm{~m}$ 


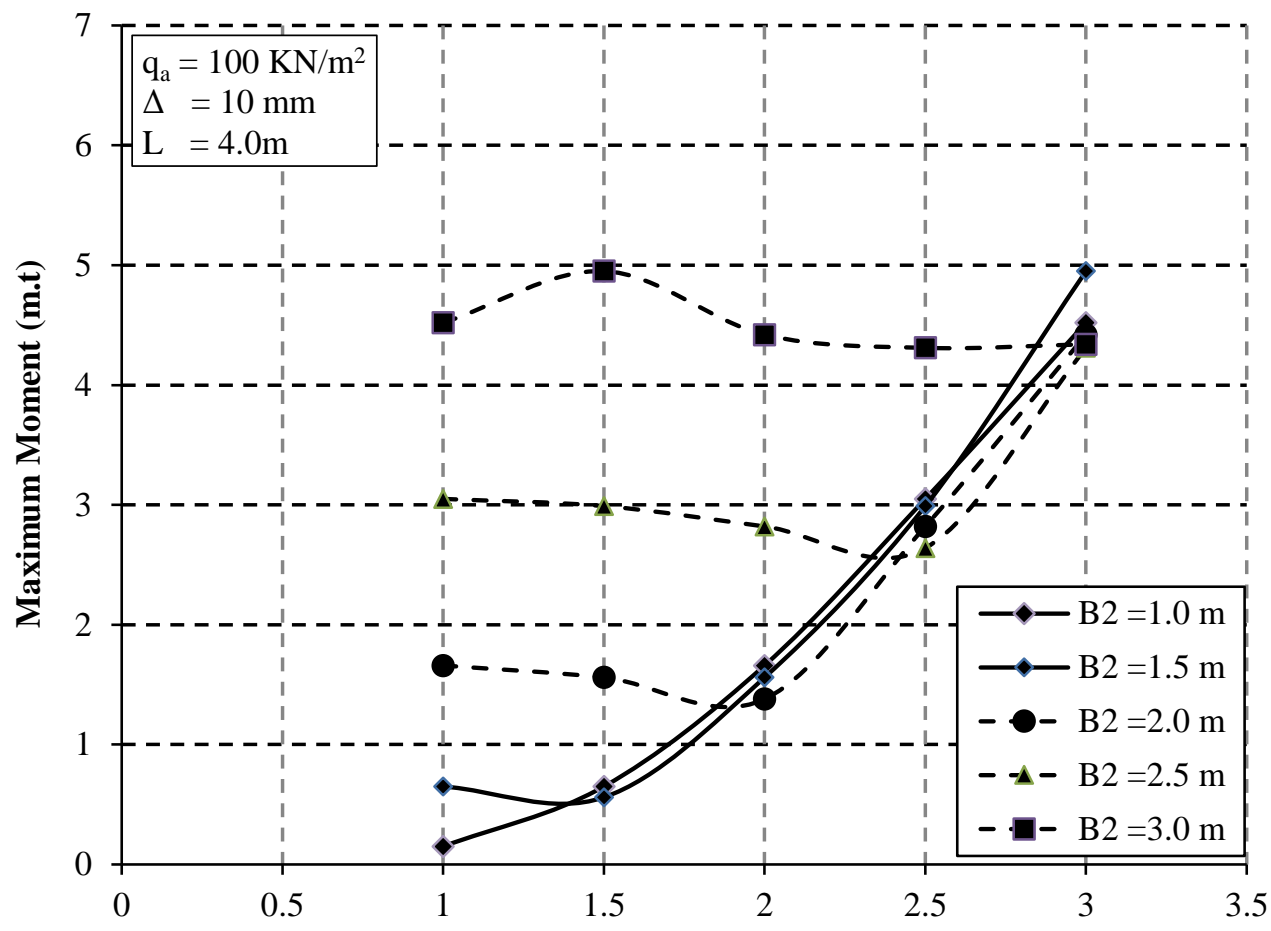

Footing Width; B1 (m)

Figure 10. Relation between footing width and end moment of the beam at differential settlement $=10 \mathrm{~mm}$, soil bearing capacity $10 \mathrm{t} / \mathrm{m}^{2}$ and the tie beam length $=4.0 \mathrm{~m}$

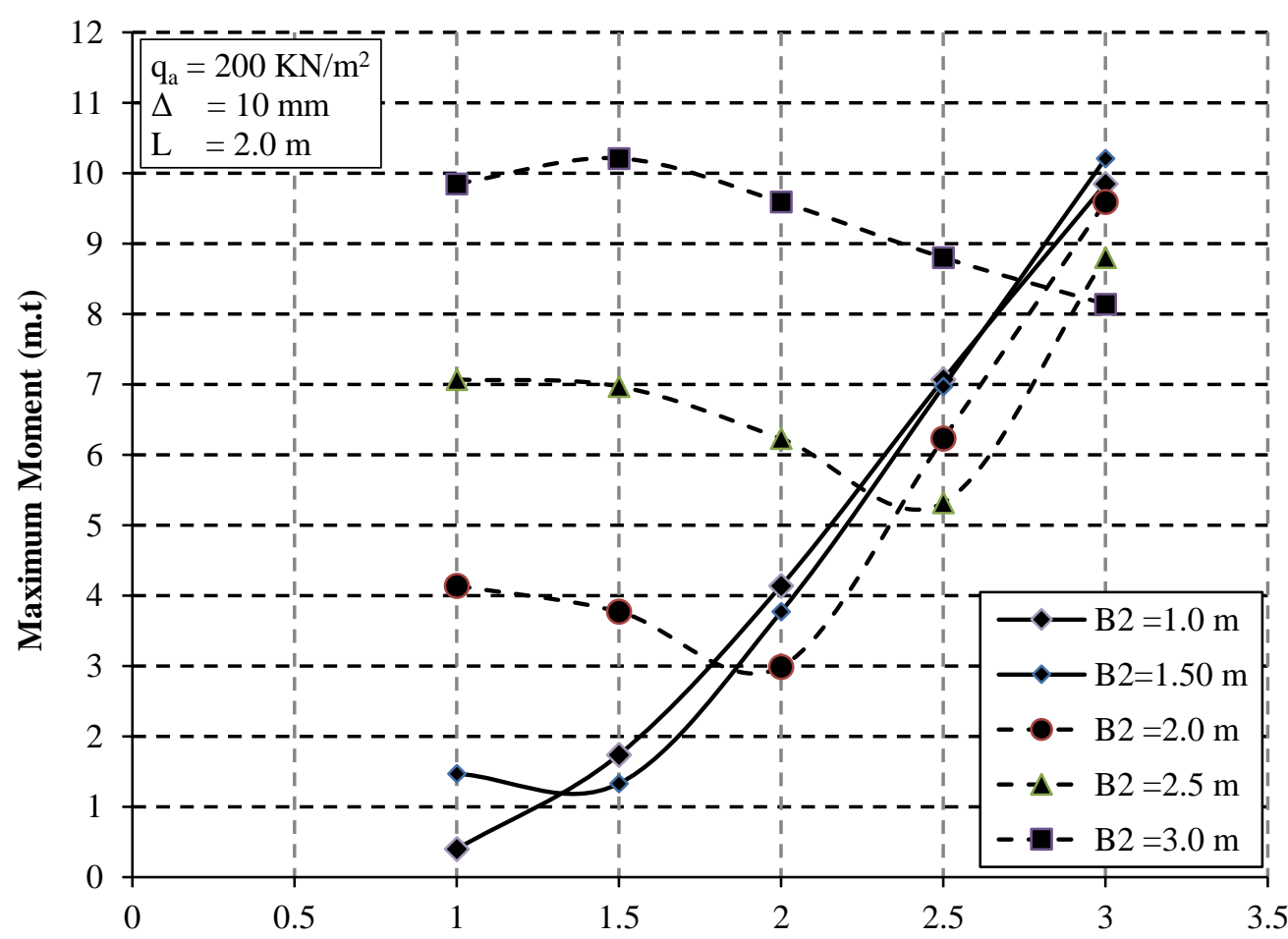

Footing Width; B1 (m)

Figure 11. Relation between footing width and end moment of the beam at differential settlement $=10 \mathrm{~mm}$, soil bearing capacity $20 \mathrm{t} / \mathrm{m}^{2}$ and the tie beam length $=2.0 \mathrm{~m}$ 


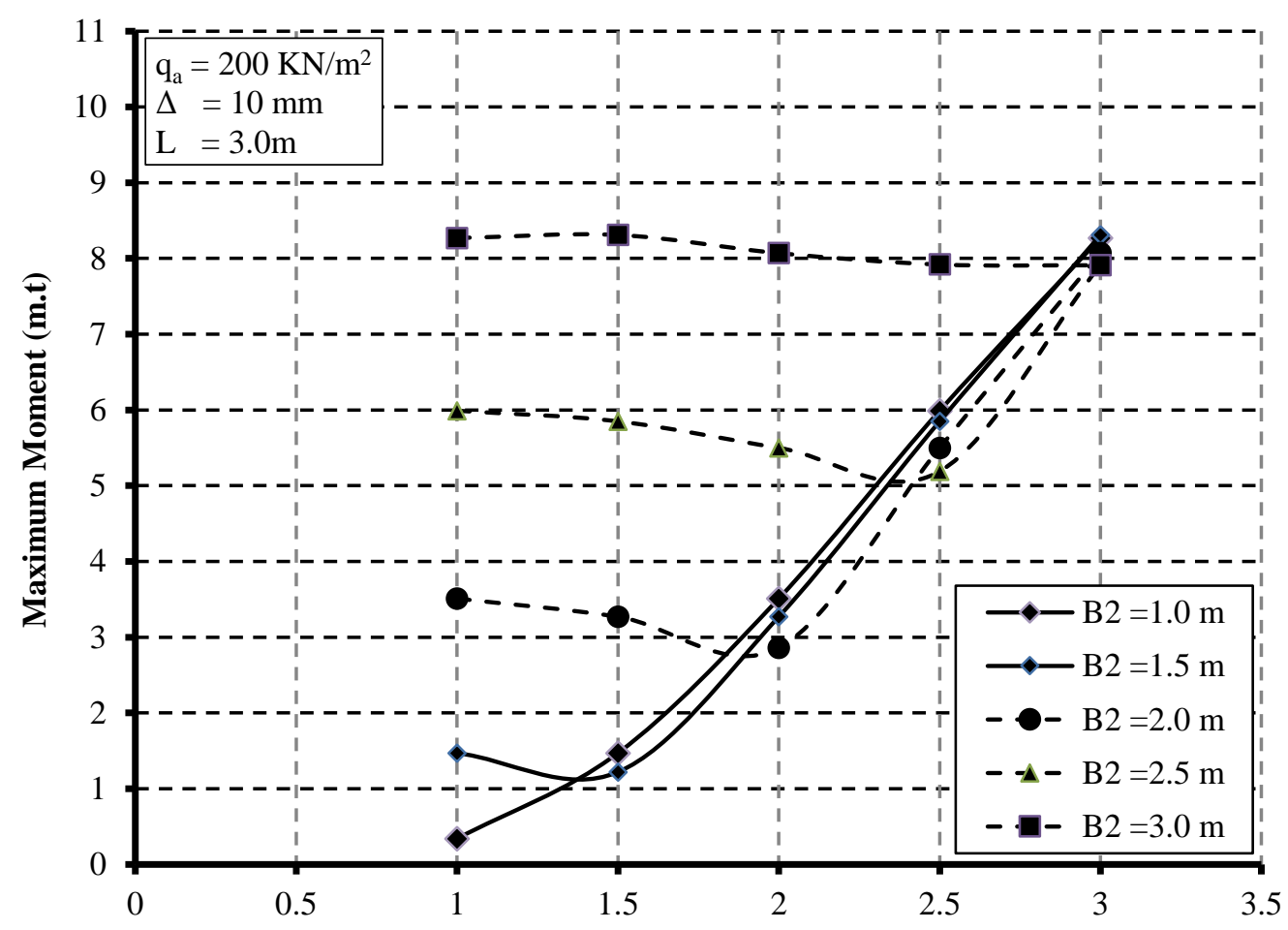

Footing Width; B1 (m)

Figure 12. Relation between footing width and end moment of the beam at differential settlement $=10 \mathrm{~mm}$, soil bearing capacity $20 \mathrm{t} / \mathrm{m}^{2}$ and the tie beam length $=3.0 \mathrm{~m}$

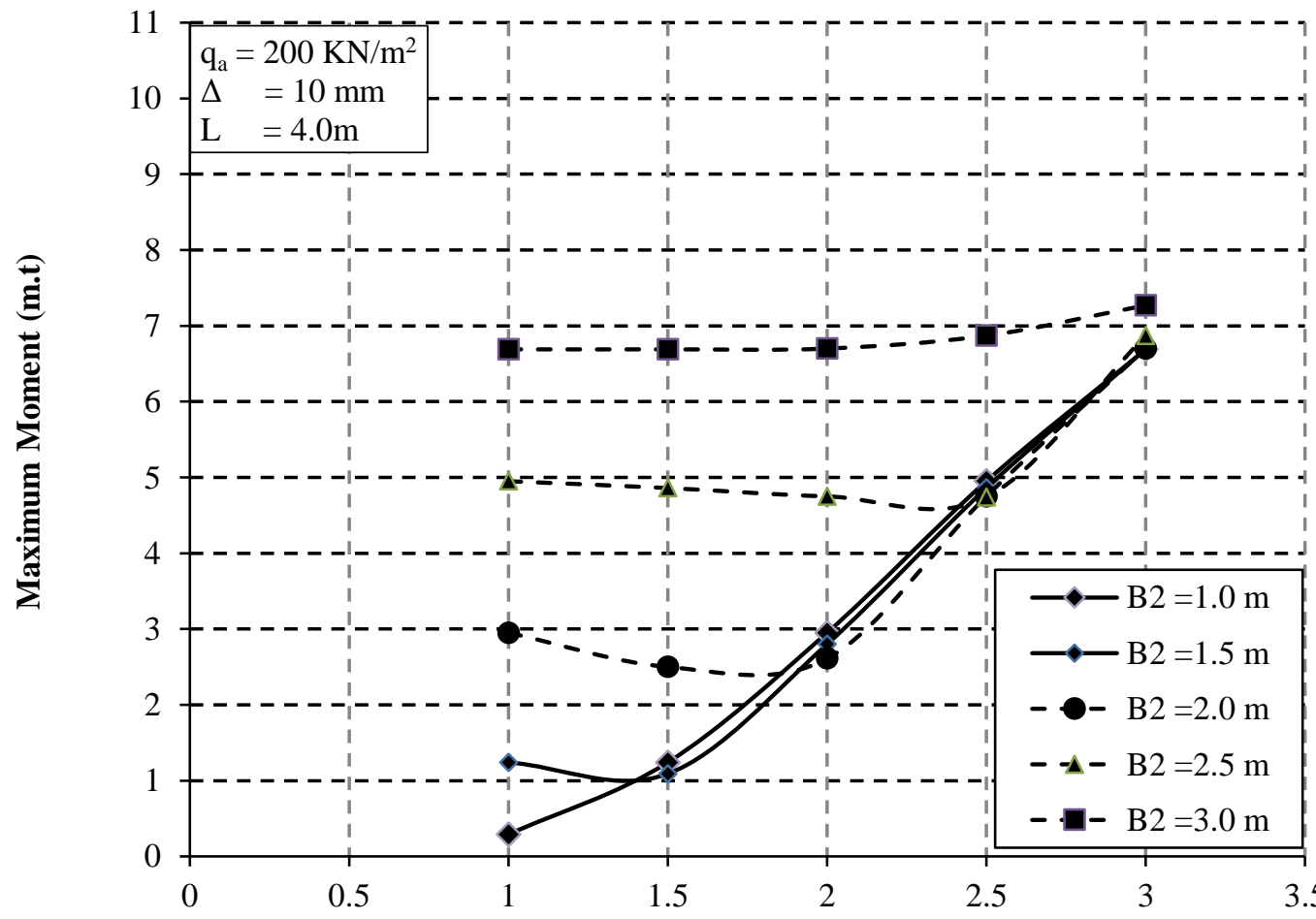

Footing Width; B1 (m)

Figure 13. Relation between footing width and end moment of the beam at differential settlement $=10 \mathrm{~mm}$, soil bearing capacity $20 \mathrm{t} / \mathrm{m}^{2}$ and the tie beam length $=4.0 \mathrm{~m}$

Generally, from the previous figures, we can draw the following notes: 
- As expected, maximum moment in tie beam is linear directly proportional to the differential settlement that agree with the theoretical study shown above.

- Also, maximum moment in tie beam is directly proportional to soil bearing capacity, footing dimensions and stiffness of tie beam (i.e. directly proportional to the moment of inertia of the tie beam cross section and the modulus of elasticity of the used concrete but inversely proportional to the tie beam length).

- The relation between the bending moment of tie beam and the parameters under study may be not enough clear because the stiffness of the assumed rotational springs, as discussed in the theoretical study, depend on all the parameters together. The created stiffness of the assumed rotational spring at one footing is sensitive to the dimensions of the other footing and soil bearing capacity but is slightly sensitive to the tie beam stiffness.

\section{Coefficient of Semi Rigid Connection}

Table 3 compares numerical and mathematical results. The fixed end moments related linearly with the modulus of elasticity of concrete, the moment of inertia and the differential settlement and inversely with the tie length as stated by Wang 2014 [13]. Figure 14. present relation between the coefficient of semi rigid connection and the footing width.

Based on result summarized in Table 3 and shown in Figure 14; the coefficient of semi rigid connection range from 0.003 to 0.13 . The coefficient of semi rigid connection has a linear relation with bearing capacity. It increases as the bearing capacity increases. In case of small footing width; the maximum moment has insignificant effect in design of the tie beam. In this case, the shear straining action has significant effect in behavior of the tie beam.

Table 3. Coefficient of semi rigid connection

\begin{tabular}{|c|c|c|c|c|c|c|c|}
\hline $\begin{array}{c}\text { Tie beam length; } \mathbf{L} \\
(\mathrm{m})\end{array}$ & $\begin{array}{l}\text { Bearing capacity } q_{a} \\
\qquad\left(K N / m^{2}\right)\end{array}$ & $\begin{array}{l}\text { Footing width at } \\
\text { B1=B2 (m) }\end{array}$ & 1 & 1.5 & 2 & 2.5 & 3 \\
\hline \multirow{6}{*}{4} & \multirow{3}{*}{100} & $M_{A}=M_{B}$ & 0.17 & 0.62 & 1.5 & 2.81 & 4.52 \\
\hline & & $M_{A}^{F}=M_{B}^{F}$ & 59.4 & 59.4 & 59.4 & 59.4 & 59.4 \\
\hline & & $\alpha_{A}=\alpha_{B}$ & 0.0029 & 0.01044 & 0.0253 & 0.0473 & 0.0761 \\
\hline & \multirow{3}{*}{200} & $M_{A}=M_{B}$ & 0.34 & 1.22 & 2.86 & 5.19 & 7.91 \\
\hline & & $M_{A}^{F}=M_{B}^{F}$ & 59.4 & 59.4 & 59.4 & 59.4 & 59.4 \\
\hline & & $\alpha_{A}=\alpha_{B}$ & 0.0057 & 0.0205 & 0.0482 & 0.0874 & 0.1332 \\
\hline
\end{tabular}

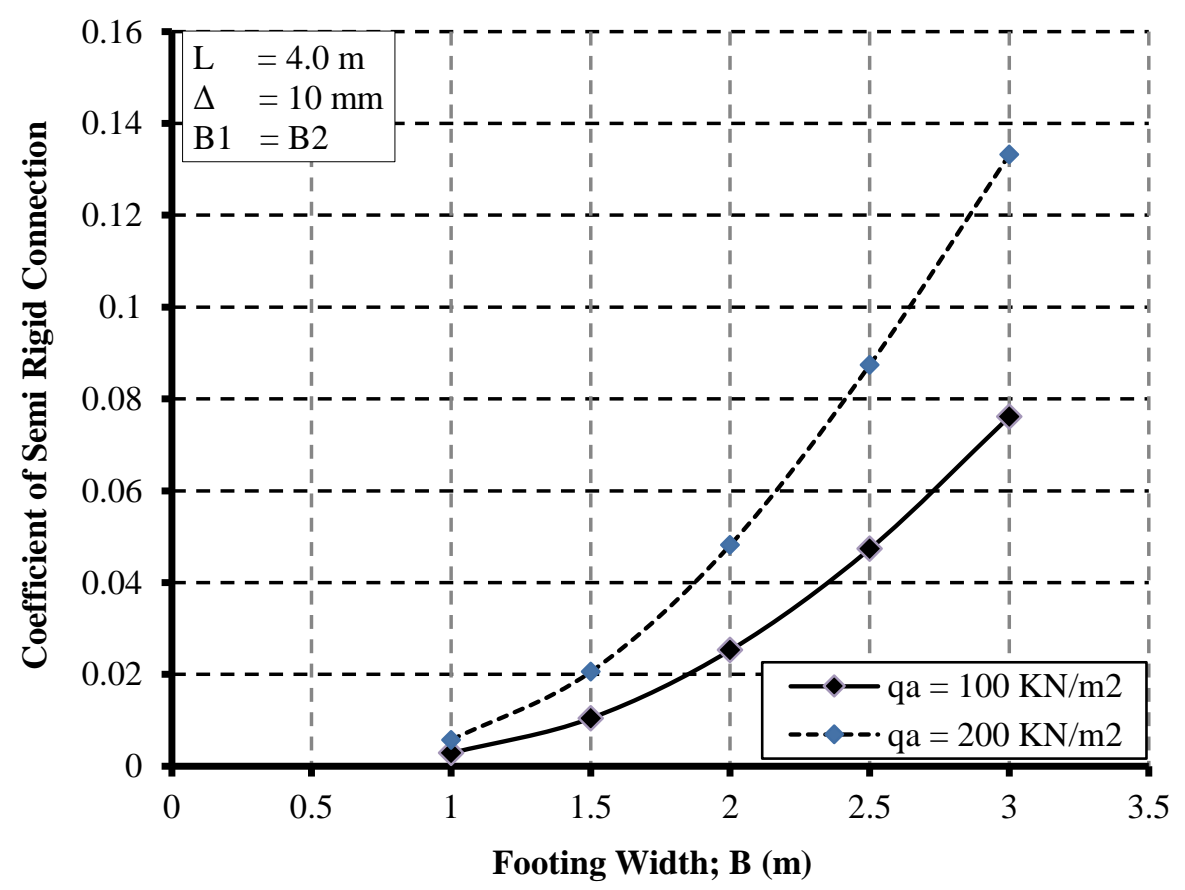

Figure 14. Relation between footing width and coefficient of semi rigid connection 


\section{Conclusion}

In this paper; three-dimensional finite element method with solid element was applied to study the tie beams behavior connected to the isolated footings under the effect of differential settlement. The following conclusion can be drawn:

- Position of the maximum end moment of the tie beam at the contact face between the isolated footing and the tie beam.

- The maximum moment of the tie beam proportional linearly with the modulus of subgrade reaction.

- The results obtained from this study are introduced in many curves to clear the relation between tie beam straining actions and each parameter may affect in the design of these tie beams (the clear length between footings, moment of inertia of tie beam, footings dimensions, soil bearing capacity and the differential settlement value).

- The analysis indicates that the bending moments carried by the tie beam increase as the isolated footing dimension increased.

Finally, the obtained curves can be of great help for design purposes of the tie beams.

\section{References}

[1] El-Kasaby, E. A. A. "Behavior of Strap Footing with Tie Beams Resting on Soil". Civil Engineering Research Magazine (CERM), Al-Azhar University, Vol.15 No.6, pp. 47-59, 1993.

[2] Elsamny, M.K., AbdElsamee, W.N., Ezz-Eldeen, H.A. and Abo-Alanwar, M.,"Settlement of Footings Connected with Tie Beams". Civil Engineering Research Magazine, 34, 2012.

[3] Elsamny, M.K., Ibrahim, M.A., Elsedeek, M.A. and Farouk, M.“Effect of Tie Beam Length on Displacement Field for Shallow Foundations". Al-Azhar University Engineering Journal, 34, 2012.

[4] Elsamny, M.K., Ibrahim, M.A., Elsedeek, M.A. and Farouk, M., "Experimental Investigation on Settlement under Isolated Footings Connected with Tie Beam". Al-Azhar University Engineering Journal, 34, 2012.

[5] Jaehwan, L. and Sangseom, J., "Experimental Study of Estimating the Subgrade Reaction Modulus on Jointed Rock Foundations", Rock Mech Rock Eng (2016) 49:2055-2064.

[6] Indian standard criteria for earthquake resistant design of structures, IS 1893: (Part 1) 2002, Part 1 General Provisions and Buildings (Fifth Revision), Bureau of Indian Standards, New Delhi.

[7] The massachusetts state building code, user's guide, to $780 \mathrm{cmr}$, sixth edition

[8] Egyptian code of practice for soil mechanics and foundation design, (ECP 202) 2012.

[9] International building code, IBC2009, International Code Council, USA.

[10] AL-Omari, R.R. and AL-Ebadi, L.H., "Effect of Tie Beam on Settlements and Moments of Footings". The 12th International Conference of International Association for Computer Method and Advances in Geomechanics (IACMAG), Goa, 1-6 October 2008.

[11] Almasri, A.H. and Taqieddin, Z.N., "Finite Element Study of Using Concrete Tie Beams to Reduce Differential Settlement between Footings". Proceedings of the 13th WSEAS International Conference on Mathematical and Computational Methods in Science and Engineering, 112-116, 2012.

[12] El Sideek, M. A., "Effect of Overlap Stress as Well as Tie Beam Length and Width on Settlement of Isolated Footings Using Finite Element". Open Journal of Civil Engineering, 4, 2014.

[13] Wang, C. K., "Intermediate Structural Analysis", Tata McGraw-Hill Education, New Delhi, India, 2014. 